\title{
Cadmium induces urokinase-type plasminogen activator receptor expression and the cell invasiveness of human gastric cancer cells via the ERK-1/2, NF-kB, and AP-1 signaling pathways
}

\author{
PHAM NGOC KHOI, YONG XIA, SEN LIAN, HO DONG KIM, DO HYUN KIM, \\ YOUNG EUN JOO, KEE-OH CHAY, KYUNG KEUN KIM and YOUNG DO JUNG
}

Research Institute of Medical Sciences, Chonnam National University Medical School, Gwangju 501-190, Republic of Korea

Received May 8, 2014; Accepted July 3, 2014

DOI: $10.3892 /$ ijo.2014.2558

\begin{abstract}
Cadmium exposure has been linked to human cancers, including stomach cancer. In this study, the effects of cadmium on urokinase-type plasminogen activator receptor (UPAR) expression in human gastric cancer cells and the underlying signal transduction pathways were investigated. Cadmium induced UPAR expression in a time- and concentration-dependent manner. Cadmium also induced uPAR promoter activity. Additionally, cadmium induced the activation of extracellular signal regulated kinase-1/2 (ERK-1/2), p38 mitogen-activated protein kinase (MAPK), and the activation of c-Jun amino terminal kinase (JNK). A specific inhibitor of MEK-1 (PD98059) inhibited cadmium-induced uPAR expression, while JNK and p38 MAPK inhibitors did not. Expression vectors encoding dominant-negative MEK-1 (pMCL-K97M) also prevented cadmium-induced uPAR promoter activity. Site-directed mutagenesis and electrophoretic mobility shift studies showed that sites for the transcription factors nuclear factor (NF)- $\kappa \mathrm{B}$ and activator protein-1 (AP-1) were involved in cadmium-induced uPAR transcription. Suppression of the cadmium-induced uPAR promoter activity by a mutatedtype NF- $\kappa \mathrm{B}$-inducing kinase and $\mathrm{I}-\kappa \mathrm{B}$ and an AP-1 decoy oligonucleotide confirmed that the activation of $N F-\kappa B$ and AP-1 are essential for cadmium-induced uPAR upregulation. Cells pretreated with cadmium showed markedly enhanced invasiveness and this effect was partially abrogated by uPARneutralizing antibodies and by inhibitors of ERK-1/2, NF- $\kappa \mathrm{B}$, and AP-1. These results suggest that cadmium induces uPAR expression via ERK-1/2, NF- $\kappa \mathrm{B}$, and AP-1 signaling pathways and, in turn, stimulates cell invasiveness in human gastric cancer AGS cells.
\end{abstract}

Correspondence to: Dr Young Do Jung, Department of Biochemistry, Chonnam National University Medical School, 5 Hakdong, Gwangju 501-190, Republic of Korea

E-mail: ydjung@chonnam.ac.kr

Key words: cadmium, uPAR, ERK-1/2, NF-кB, AP-1, cell invasion

\section{Introduction}

Cadmium is a toxic metal, classified as a human carcinogen by the International Agency for Research on Cancer (1). There are probable associations between long-term environmental exposure to cadmium and an increased risk of mortality from stomach, esophageal and lung cancers (2). However, the molecular and cellular mechanisms underlying cadmiummediated tumorigenic effects in tissue remain unclear. Studies using in vitro cell culture and in vivo animal models have revealed some of the mechanisms underlying cadmium carcinogenesis. Cadmium may induce genotoxic effects, such as 8-ox-7,8-dihydro-2'-deoxyguanosine adducts, DNA strand breaks, chromosomal aberration, and gene mutations, in a variety of in vitro cell culture and animal experimental systems (3). Most of the genotoxic events induced by cadmium are mediated through the generation of reactive oxygen species (ROS) (4). Cadmium also activates gene expression of c-myc and c-Jun, inhibits tumor suppressor genes, such as p53 and p27, and accelerates the proliferation of cells that are already stimulated with organic carcinogens $(5,6)$.

Cadmium has been reported to activate mitogen-activated protein kinase (MAPKs) signaling. In mammals, MAPKs consist of extracellular signal-regulated kinases (ERK), c-Jun N-terminal kinases (JNK), and p38 MAPK. Cadmium activates ERK signaling and elevates the expression of a key downstream proangiogenic molecule, hypoxia-inducible factor-1 (HIF-1), in immortalized lung epithelial cells (7). The JNK pathway has also been reported to be involved in the acquisition of apoptotic resistance in cadmium carcinogenesis, contributing to both tumor initiation and malignant progression (8). Additionally, cadmium has been reported to induce diverse modulation of the transcription patterns of $\mathrm{p} 38$ MAPK isoform genes and the accumulation of related protein products in breast cancer cells. However, the roles of MAPK signals in cadmium-mediated cell invasion and migration have not yet been explored.

The process of cancer cell invasion and migration is multifactorial, requiring the coordinated action of cell-secreted proteolytic enzymes and their inhibitors (9). A recent study has shown that cadmium treatment increased the potential of cells to invade and migrate (10). Urokinase-type plasminogen 
activator (UPA), its inhibitors, and the uPA receptor (UPAR) form a complex proteolytic system that has been implicated in cancer invasion and metastasis. As a serine protease, uPA has the ability to convert inactive plasminogen to active plasmin by binding to its receptor, uPAR. The UPA-uPAR interaction can affect independently cell motility, integrin function, and gene expression (11). uPAR expression has been shown to play important roles in the invasion and metastasis of a number of cancers, such as gastric (12), prostate (13) and breast cancers (14). In addition to mediating proteolysis, this receptor also appears to mediate cell signaling, proliferation, and survival, and these observations have suggested novel ways to target uPAR. To examine the role and mechanisms of cadmium in regulating invasion and migration, we investigated the effects of cadmium on mitogen-activated protein kinase signaling and the downstream transcription factors, NF- $\kappa \mathrm{B}$ and AP-1, of uPAR in gastric cancer AGS cells.

\section{Materials and methods}

Cell culture and reagents. Human gastric cancer AGS cells were purchased from the American Type Culture Collection (Manassas, VA, USA), and MKN28 and SNU638 cells were obtained from the Korean Cell Line Bank (Seoul, Korea). The cells were incubated in RPMI-1640 supplemented with $10 \%$ fetal bovine serum (FBS), $100 \mathrm{IU} / \mathrm{ml}$ penicillin and $100 \mathrm{mg} / \mathrm{ml}$ streptomycin in a humidified atmosphere containing $5 \% \mathrm{CO}_{2}$ incubator at $37^{\circ} \mathrm{C}$. To determine the effects of cadmium (Sigma, St. Louis, MO, USA) on uPAR expression, cells were harvested at various intervals and the levels of UPAR mRNA were measured by RT-PCR analysis. To examine the effects of cadmium on ERK1/2, JNK, and p38 MAPK activation, cells were harvested at various intervals and phosphorylated and total protein levels were determined by western blot analysis. To examine the role of specific signaling pathways in UPAR induction by cadmium, cells were pretreated with $25 \mu \mathrm{M}$ PD98059 (a MEK inhibitor, New England Biolabs Inc., Beverly, MA, USA), $10 \mu \mathrm{M}$ SP600125 (a c-Jun-N-terminal kinase inhibitor, Calbiochem, San Diego, CA, USA), $5 \mu \mathrm{M}$ SB203580 (a specific p38 MAPK inhibitor; Calbiochem), $20 \mu \mathrm{M}$ Bay11-7082 (NF- $\kappa \mathrm{B}$ inhibitor, Calbiochem), or curcumin (AP-1 inhibitor, Sigma) for $1 \mathrm{~h}$ prior to cadmium treatment. The levels of UPAR mRNA were then measured by northern blot and RT-PCR analysis.

$R T-P C R$. Cells were incubated overnight in medium containing $1 \%$ FBS and then treated with specific inhibitors for $1 \mathrm{~h}$ prior to cadmium treatment for $4 \mathrm{~h}$. After the incubation, total cellular RNA was isolated from the cells using the TRIzol reagent (Invitrogen, Carlsbad, CA, USA). Total RNA ( $1 \mu \mathrm{g})$ was used for the first-strand cDNA synthesis using random primers and Superscript reverse transcriptase (Invitrogen). The cDNA was subjected to PCR amplification with the primer sets for glyceraldehyde 3-phosphate dehydrogenase (GAPDH) and uPAR. The specific primers sequences were GAPDH sense, 5'-TTG TTG CCA TCA ATG ACC CC-3'; GAPDH antisense, 5'-TGA CAA AGT GGT CGT TGA GG-3' (836 bp) and uPAR sense, 5'-CAC GAT CGT GCG CTT GTG GG-3', and uPAR antisense, 5'-TGT TCT TCA GGG CTG CGG CA-3' (285 bp). The PCR conditions were 30 cycles of denaturation at $95^{\circ} \mathrm{C}$ for
$20 \mathrm{sec}$, annealing at $53^{\circ} \mathrm{C}$ for $30 \mathrm{sec}$, and extension at $72^{\circ} \mathrm{C}$ for $40 \mathrm{sec}$. The products were electrophoresed in $1.5 \%$ agarose gel containing ethidium bromide.

Measurement of $U P A R$ promoter activity. The transcriptional regulation of UPAR was examined by the transient transfection of a UPAR promoter luciferase reporter construct (pGL3-uPAR). The plasmid pGL3-uPAR promoter (15) was provided by Dr Y. Wang (Australian National University). AGS cells $\left(5 \times 10^{5}\right)$ were seeded and grown until they reached $60-70 \%$ confluence, then pRL-TK (an internal control plasmid containing the herpes simplex thymidine kinase promoter linked to the constitutively active Renilla luciferase reporter gene) and pGL3-uPAR were cotransfected into the cells using FuGENE (Boehringer-Mannheim, Mannheim, Germany) according to the manufacturer's protocol. pRL-TK was transfected as an internal control. Cells were incubated in the transfection medium for $20 \mathrm{~h}$ and treated with $0-20 \mu \mathrm{M}$ cadmium for $4 \mathrm{~h}$. The effects of signaling inhibitors on UPAR promoter activity were determined by pretreating cells with the inhibitors for $1 \mathrm{~h}$ prior to the addition of cadmium. The cotransfection studies were performed in the presence or absence of the AP-1 decoy oligodeoxynucleotides (ODNs) or MEK-1 (pMCL-K97M), I- $\kappa \mathrm{B} \alpha$, I- $\kappa \mathrm{B} \beta$, or NF- $\kappa \mathrm{B}$-inducing kinase (NIK). The phosphorothioate double-stranded ODNs with sequences against the AP-1 binding site (5'-CAC TCA GAA GTC ACT TC-3' and 3'-GAA GTG ACT TCT GAG CTG-5') were prepared (Genotech, St. Louis, MO, USA) and annealed (AP-1 decoy ODNs). The expression vector encoding the inactive MEK-1 (pMCL-K97M) was a gift from Dr N.G. Ahn (University of Colorado). The dominant negative mutants of I- $\kappa \mathrm{B} \alpha$ and $\mathrm{I}-\kappa \mathrm{B} \beta$ and NIK were provided by Dr D.W. Ballard (Vanderbilt University, Nashville) and Dr W.C. Greene (University of California), respectively. The importance of $\mathrm{NF}-\kappa \mathrm{B}$ and AP-1 during the induction of UPAR by cadmium was examined by transfecting AGS cells with pGL3-uPAR, in which the NF- $\kappa$ B and AP-1 sites had been mutated. After incubation, the cells were harvested and lysed with passive lysis buffer (Dual-Luciferase Reporter Assay system; Promega, Madison, WI, USA), and luciferase activity was measured using a luminometer according to the manufacturer's protocol.

Western blot analysis. Cells pretreated with 0-20 $\mu \mathrm{M}$ cadmium for various periods were washed in phosphate-buffered saline (PBS), detached using trypsin-EDTA buffer, and stored at $-70^{\circ} \mathrm{C}$ until needed. The protein was extracted with RIPA buffer (1\% NP-40, $0.5 \%$ sodium deoxycholate, $0.1 \%$ sodium dodecyl sulfate) and protease inhibitors (aprotinin, leupeptin, phenylmethanesulfonyl fluoride, benzamidine, trypsin inhibitor, sodium orthovanadate). Then, $50 \mu \mathrm{g}$ of the protein was separated by $10 \%$ SDS-PAGE and transferred to PVDF membranes. The membranes were blocked in a PBS solution containing 5\% non-fat dry milk, incubated with primary antibody in blocking solution overnight at $4^{\circ} \mathrm{C}$, and washed three times with $0.1 \%$ Tween-20 in Tris-buffered saline (TBST) at 10 -min intervals. Horseradish peroxidase-conjugated secondary antibody (Amersham, Arlington Heights, IL, USA) was used to detect the immunoreactive proteins by chemiluminescence. The following antibodies were used: anti-uPAR (American Diagnostica, Greenwich, CT, USA), anti-phospho- 
p44/42 MAPK (ERK-1/2) (Cell Signaling Technology, Danvers, MA, USA), anti-phospho-JNK (Cell Signaling Technology), and anti-phospho-p38 MAPK (Cell Signaling Technology). Total protein levels were assayed by washing the blotted membrane with a stripping solution consisting of $100 \mathrm{mM}$ 2-mercaptoethanol, 2\% SDS, and $62.5 \mathrm{mM}$ Tris- $\mathrm{HCl}, \mathrm{pH}$ 6.7, for $30 \mathrm{~min}$ at $50^{\circ} \mathrm{C}$, and the membrane was then reprobed with the anti- $\beta$-actin (Sigma-Aldrich), anti-ERK-1/2 (Cell Signaling Technology), anti-JNK-2 (Cell Signaling Technology), or antip38 MAPK (Cell Signaling Technology) monoclonal antibody.

Extraction of nuclear proteins. AGS cells at $80-90 \%$ confluence were incubated overnight in medium containing 5\% FBS and then treated with $0-30 \mu \mathrm{M}$ cadmium. The cells were then resuspended in $500 \mu \mathrm{l}$ cold buffer A [50 mM Tris, pH 7.4, $150 \mathrm{mM} \mathrm{NaCl}, 0.2 \mathrm{mM}$ EDTA, 3\% (v/v) glycerol, and $1.5 \mathrm{mM}$ $\left.\mathrm{MgCl}_{2}\right]$. After the cells had been allowed to swell for $5 \mathrm{~min}$ on ice, they were lysed with $500 \mu 1$ of buffer B (identical to buffer A except containing $0.05 \%$ Nonidet P-40). The homogenate was gently layered onto an equal volume cushion of buffer C [10 mM Tris, pH 7.4, 25\% (v/v) glycerol, and $1.5 \mathrm{mM}$ $\left.\mathrm{MgCl}_{2}\right]$ and centrifuged $(12,000 \mathrm{x} \mathrm{g}, 5 \mathrm{~min})$. The white nuclear pellet was resuspended in $75 \mu \mathrm{l}$ of a cold high-salt lysis buffer (20 mM HEPES, pH 7.9, $400 \mathrm{mM} \mathrm{NaCl}, 1 \mathrm{mM}$ EDTA, $1 \mathrm{mM}$ DTT, and $1 \mathrm{mM}$ PMSF). This suspension was agitated for $30 \mathrm{~min}$ at $40^{\circ} \mathrm{C}$ and then microcentrifuged $\left(15 \mathrm{~min}, 4^{\circ} \mathrm{C}\right)$. The resulting supernatant was stored in aliquots at $-80^{\circ} \mathrm{C}$.

Electrophoretic mobility shift assay (EMSA). EMSA was carried out using a Gel Shift assay system (Promega). Briefly, oligonucleotides containing the consensus sequences of AP-1 (5'-CGC TTG ATG AGT CAG CCG GAA-3') and NF- $\kappa$ B (5'-AGT TGA GGG GAC TTT CCC AGG-3') were endlabeled with $\left[\gamma^{32} \mathrm{P}\right]$ adenosine triphosphate $(3000 \mu \mathrm{Ci} / \mathrm{mmol}$; Amersham Pharmacia Biotech., Buckinghamshire, UK) using T4 polynucleotide kinase, purified with Microspin G-25 columns (Sigma-Aldrich) and used as the probe for EMSA. The nuclear extract proteins $(6 \mu \mathrm{g})$ were pre-incubated with the binding buffer [10 $\mathrm{mM}$ Tris- $\mathrm{HCl}, \mathrm{pH} 7.5,50 \mathrm{mM} \mathrm{NaCl}$, $0.5 \mathrm{mM}$ EDTA, $1 \mathrm{mM} \mathrm{MgCl} 2,0.5 \mathrm{mM}$ DTT, $4 \%$ (v/v) glycerol, and $0.05 \mathrm{mg} / \mathrm{ml}$ poly $(\mathrm{dI}-\mathrm{dC})]$ for $5 \mathrm{~min}$ and then incubated with the radiolabeled probe for $15 \mathrm{~min}$ at $37^{\circ} \mathrm{C}$. Each sample was electrophoresed in a $5 \%$ non-denaturing polyacrylamide gel in $0.5 \mathrm{X}$ TBE buffer. The gel was then dried and subjected to autoradiography.

Transient transfection of AP-1 and $N F-\kappa B$ reporters. The AP-1 and NF- $\kappa B$ reporter constructs were purchased from Clontech (Palo Alto, CA, USA). Once the cells had reached 60-70\% confluence, they were washed with RPMI-1640 and incubated in medium without serum or antibiotics for $18 \mathrm{~h}$. The cells were then transfected with AP-1 and NF- $\mathrm{KB}$ reporters in the pGL3 vector using Lipofectamine 2000 (Invitrogen). Reportertransfected cells were treated with 0-30 $\mu \mathrm{M}$ cadmium for $4 \mathrm{~h}$. After incubation, the luciferase activity was measured using a luminometer.

Matrigel invasion assay. A cell invasion assay was performed using BioCoat Matrigel invasion chambers (Becton-Dickinson, Bedford, MA, USA) with $10 \%$ FBS as the chemoattractant in
A

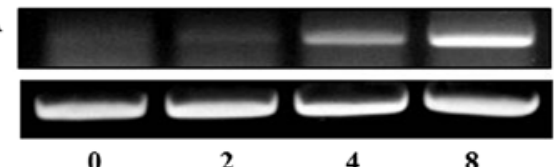

uPAR

GAPDH

Cd $(\mathrm{h}, 20 \mu \mathrm{M})$

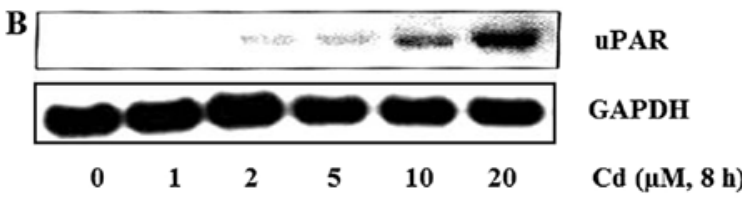

C

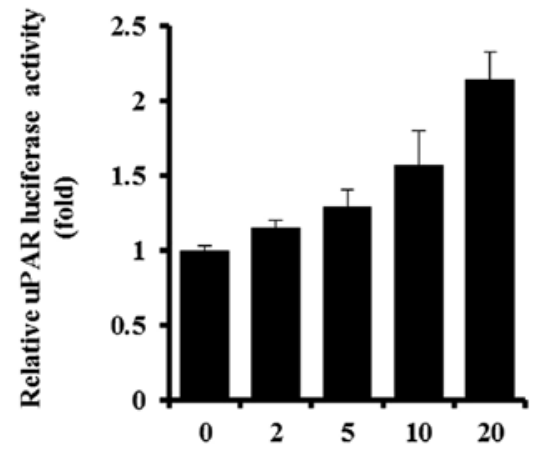

$\mathrm{Cd}(\mu \mathrm{M}, 8 \mathrm{~h})$

D

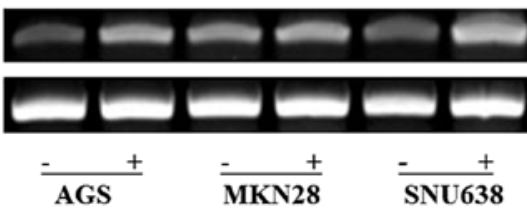

uPAR

GAPDH

Cd $(4 \mathrm{~h}, 20 \mu \mathrm{M})$

Figure 1. Induction of uPAR by cadmium in gastric cancer cells. To determine the effects of cadmium on UPAR mRNA and protein expression in AGS cells, RT-PCR (A) and western blot analysis (B) was performed, respectively. Cells were incubated with $20 \mu \mathrm{M}$ of cadmium for $0-8 \mathrm{~h}(\mathrm{~A})$. The cells were incubated with the indicated concentration of cadmium $(0-20 \mu \mathrm{M})$ for $8 \mathrm{~h}(\mathrm{~B})$ AGS cells were transiently transfected with a pGL3-uPAR reporter construct. The transfected cells were incubated with $0-20 \mu \mathrm{M}$ cadmium for $4 \mathrm{~h}$ and luciferase activity was determined using a luminometer (C). AGS, MKN28, and SNU638 cells were incubated with $20 \mu \mathrm{M}$ of cadmium for $4 \mathrm{~h}$, and uPAR mRNA expression in the cell lysates was determined by RT-PCR (D).

the lower chamber. AGS cells $\left(10^{5}\right)$ in $300 \mu$ l were added to each chamber with cadmium and allowed to invade the Matrigel for $24 \mathrm{~h}$. The non-invading cells on the upper surface of each membrane were removed from the chamber, and the invading cells on the lower surface of each membrane were stained with the Quick-Diff stain kit (Becton-Dickinson, Franklin Lakes, NJ, USA). After two washes with water, the chambers were allowed to air-dry. The number of invading cells was counted using a phase-contrast microscope. To determine the effects of anti-uPAR antibody and inhibitors of ERK-1/2, NF- $\kappa B$ and AP-1 on cadmium-induced cell invasion, AGS cells were preincubated with a neutralizing antibody to UPAR or nonspecific IgG, inhibitors of ERK-1/2, NF- $\kappa B$ and AP-1 for $1 \mathrm{~h}$, and added to $20 \mu \mathrm{M}$ cadmium for $4 \mathrm{~h}$.

Statistical analyses. Data are shown as means $\pm \mathrm{SD}$, and represent the means of at least three separate experiments each performed in triplicate. Differences between data sets 

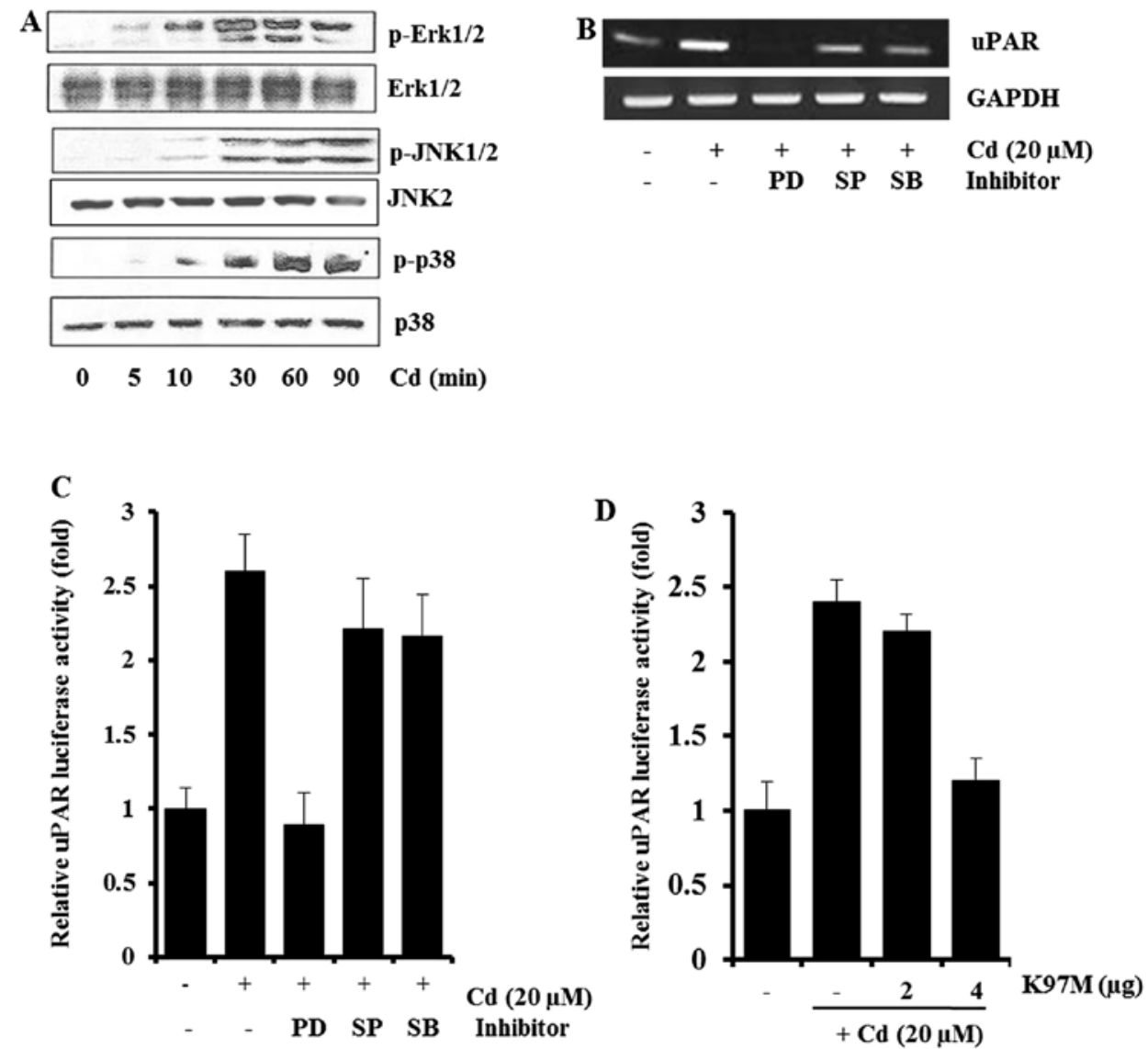

Figure 2. Involvement of MAPK in cadmium-induced uPAR expression in AGS cells. AGS cells were incubated with $20 \mu \mathrm{M}$ cadmium for 0-90 min, and cell lysates were analyzed for phospho-Erk1/2, phospho-JNK1/2, and phospho-p38 MAPK by western blot analysis (A). AGS cells pretreated with $25 \mu$ M PD98059 (PD), $10 \mu \mathrm{M}$ SP600125 (SP), or $5 \mu \mathrm{M}$ SB203580 (SB) for $1 \mathrm{~h}$ were incubated with $20 \mu \mathrm{M}$ cadmium for $4 \mathrm{~h}$. After incubation, uPAR mRNA in the cell lysates were determined by RT-PCR (B). Cells transiently transfected with pGL3-uPAR after being pretreated with PD98059 (PD), SP600125 (SP), or SB203580 (SB) were incubated with $20 \mu \mathrm{M}$ cadmium for $4 \mathrm{~h}$. After incubation, the cells were lysed, and luciferase activity was measured using a luminometer (C). An expression vector encoding a mutated MEK-1 (K97M) was cotransfected with pGL3-uPAR into AGS cells. After incubation with $20 \mu \mathrm{M}$ cadmium for $4 \mathrm{~h}$, luciferase activities were determined using a luminometer (D). The data represent means \pm standard deviations from triplicate measurements.

were determined using Student's t-test. Differences described as significant in the text correspond to $\mathrm{P}<0.05$.

\section{Results}

Effects of cadmium on UPAR expression in gastric cancer cells. To determine the effects of cadmium on uPAR expression in gastric cancer AGS cells, cells were treated with cadmium and the expression of UPAR were measured by RT-PCR and western blot analyses. As shown in Fig. 1A, cadmium induced uPAR mRNA expression in a time-dependent manner in AGS cells. The UPAR mRNA expression increased appreciably $4 \mathrm{~h}$ after addition of cadmium to the cells. We also found that cadmium induced the UPAR protein in a dose-dependent manner at $0-20 \mu \mathrm{M}$ (Fig. 1B). Next, we sought to examine the effect of cadmium on transcriptional regulation of the uPAR gene. AGS cells were transiently transfected with the promoter-reporter construct (pGL3-uPAR) containing the human UPAR promoter and the luciferase gene. The AGS cells transfected with pGL3-uPAR showed an increase in promoter activity with cadmium exposure in a dose-dependent manner (Fig. 1C). Cadmium at the concentrations used in this experiment did not affect cell viability (data not shown). Gastric cancer AGS, MKN28 and SNU638 cells were used to explore whether cadmium was able to induce uPAR expression in various gastric cancer cells. As shown in Fig. 1D, cadmium induced UPAR expression in AGS, MKN28, and SNU638. Collectively, these results demonstrate that cadmium upregulated the expression of the UPAR gene in human gastric cancer cells.

Involvement of MAPK in cadmium-induced UPAR $m R N A$ expression. To determine the signaling pathways involved in uPAR induction by cadmium, AGS cells exposed to cadmium for various periods were examined for levels of phospho- and total ERK-1/2, JNK, and p38 MAPK. Cadmium treatment resulted in marked increases in ERK-1/2, JNK, and p38 MAPK phosphorylation within $30 \mathrm{~min}$ and the increased levels were maintained for 60-90 min. The levels of total ERK-1/2, JNK2, and p38 MAPK were not significantly altered after cadmium treatment (Fig. 2A).

To further examine the specific roles of ERK-1/2, JNK, and p38 MAPK in cadmium-induced uPAR expression, AGS cells were pretreated with $25 \mu \mathrm{M}$ PD98059 (MEK inhibitor), $10 \mu \mathrm{M}$ SP600125 (JNK inhibitor), or $5 \mu \mathrm{M} \mathrm{SB} 203580$ (p38 MAPK inhibitor) before cadmium treatment. As shown in Fig. 2B, the 

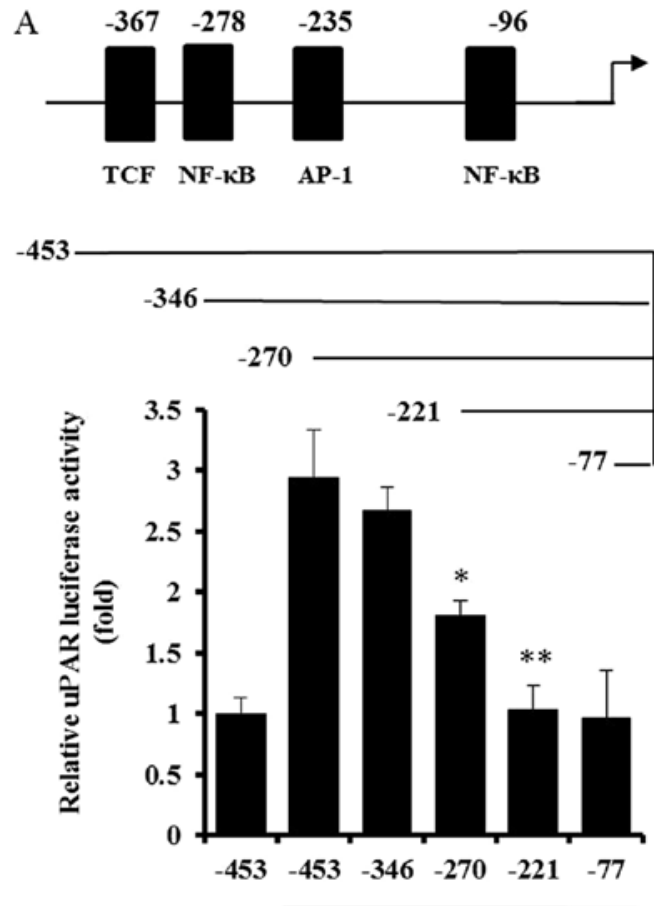

$+\mathrm{Cd}(20 \mu \mathrm{M})$

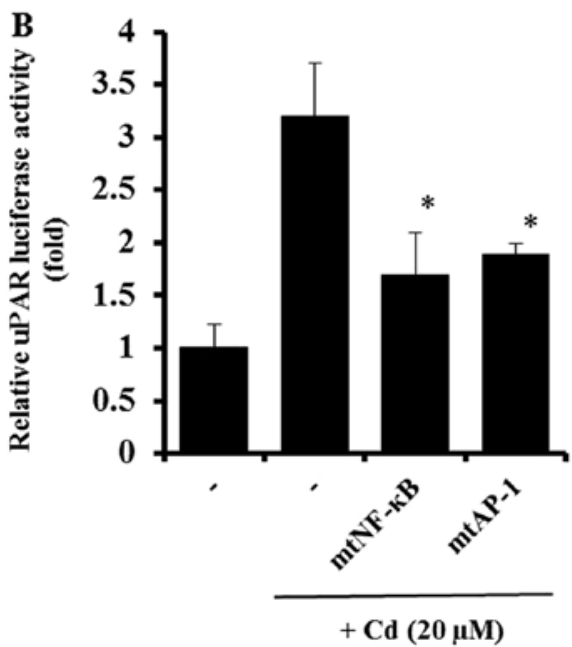

Figure 3. Effects of sequential deletion and site-specific mutations in the uPAR promoter region on cadmium-induced uPAR promoter activity. The uPAR promoter was sequentially deleted in the 5'-flanking region and the promoter luciferase construct was transiently transfected into AGS cells (A). The uPAR promoter was mutated in the NF- $\kappa \mathrm{B}$ and AP-1 sites (mtNF- $\kappa \mathrm{B}$ and mtAP-1) (converted NF- $\kappa$ B site GGGAGGAGT to GGATCCAGT and converted AP-1 site TCCATGAGTCA to TCGGAATTCCA) and the promoter luciferase construct was transiently transfected into AGS cells. The transfected cells were incubated with $20 \mu \mathrm{M}$ cadmium for $4 \mathrm{~h}$. After incubation, the cells were lysed and the luciferase activity was measured using a luminometer. Data represent the mean $\pm \mathrm{SD}$ from triplicate measurements. ${ }^{*} \mathrm{P}<0.05$, vs. -346 ; ${ }^{* *} \mathrm{P}<0.05$, vs. -270 in (A). ${ }^{*} \mathrm{P}<0.05$, vs. with cadmium only in (B).

levels of UPAR in AGS cells pretreated with MAPK inhibitors decreased. In particular, the MEK inhibitor PD98059 almost completely blocked cadmium-induced uPAR mRNA expression, by RT-PCR analysis. When the transfected cells were pretreated with $25 \mu \mathrm{M}$ PD98059 (MEK inhibitor) for $1 \mathrm{~h}$ before cadmium treatment, the induction of UPAR promoter activity was inhibited markedly (Fig. 2C). Consistent with the results of Fig. 2B and $\mathrm{C}$, when the dominant-negative mutant of MEK-1 (K97M) was cotransfected with pGL-uPAR in AGS cells, induction of the UPAR promoter activity by cadmium was inhibited dose-dependently (Fig. 2D). These results suggest that ERK-1/2 signaling pathways are involved in the cadmium-induced activation of UPAR transcription.

Effect of cadmium on the activation of transcription factors during $u P A R$ induction. As shown in Figs. 1 and 2, cadmium treatment increased the activity of the UPAR promoter in AGS cells. A deletion study was performed to explore the uPAR promoter and its specific sequence-activity characteristics. Deletion of the upstream (5') region of position -346 bp had little effect on cadmium-induced UPAR promoter activation. In contrast, elimination of the region between positions -346 and -270 bp resulted in a substantial decrease in promoter activity, and another cadmium-inducible element was identified between nucleotides -270 and -221 (Fig. 3A). The uPAR gene fragments spanning positions -346 to -270 bp and -270 to -221 bp contain DNA-protein interaction sites for the transcription factors NF- $\kappa \mathrm{B}(-278)$ and AP-1 (-235), respectively. To study the importance of the NF- $\mathrm{KB}$ and AP-1 sites in UPAR induction by cadmium, AGS cells were transfected with sitespecific mutant forms of the UPAR promoter linked to the luciferase gene. As shown in Fig. 3B, mutation of either the $\mathrm{NF}-\kappa \mathrm{B}$ or AP-1 binding site significantly decreased uPAR promoter activity, suggesting that both NF- $\kappa \mathrm{B}$ and AP-1 are important in uPAR upregulation by cadmium. This was further supported by EMSA and inhibitor studies. In EMSA, cadmium treatment caused a marked increase in the amount of $\mathrm{NF}-\kappa \mathrm{B}$ that could form a complex with the radiolabeled oligonucleotide probe (Fig. 4A). Consistent with the EMSA result, cadmium treatment caused an increase in NF- $\kappa \mathrm{B}$-dependent

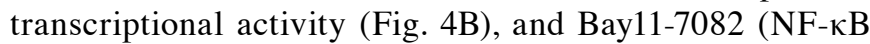
inhibitor) partially blocked the cadmium-induced uPAR expression, by RT-PCR (Fig. 4C). The involvement of NF- $\kappa \mathrm{B}$ in the induction of uPAR by cadmium was confirmed by cotransfecting AGS cells with a UPAR promoter reporter and dominant-negative mutant forms of $\mathrm{NF}-\kappa \mathrm{B}$-related molecules. As shown in Fig. 4D, the expression of dominant-negative mutant forms of NIK, I- $\kappa \mathrm{B} \alpha$, or I- $\kappa \mathrm{B} \beta$ resulted in a decrease in the cadmium-induced uPAR promoter activity. Additionally, involvement of AP-1 in cadmium-induced uPAR expression was examined. As shown in Fig. 5A and B, cadmium treatment caused an increase in the amount of AP-1-DNA complex and AP-1-dependent transcriptional activity. AP-1 inhibitors (curcumin and the AP-1 decoy) blocked cadmium-induced UPAR expression and UPAR promoter activity, respectively (Fig. 5C and D). These results indicated that NF- $\kappa$ B and AP-1 may be key molecules in cadmium-induced uPAR expression.

Effects of cadmium on the invasion of AGS cells. It has been suggested that expression of UPAR is required for the invasive phenotype of cancer cells. To evaluate the role of cadmiuminduced uPAR during AGS cell invasion, cells were incubated with specific antibodies against UPAR in a modified Boyden invasion chamber. As shown in Fig. 6, cell invasiveness was increased markedly by incubation with cadmium. However, the cadmium-treated cells partially lost the increased Matrigel 
A

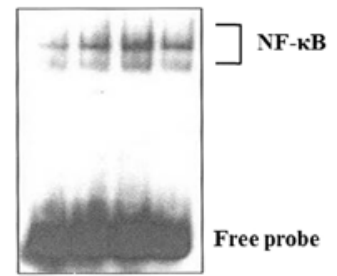

$\begin{array}{lllll}0 & 10 & 20 & 30 & \mathrm{Cd}(\mu \mathrm{M})\end{array}$

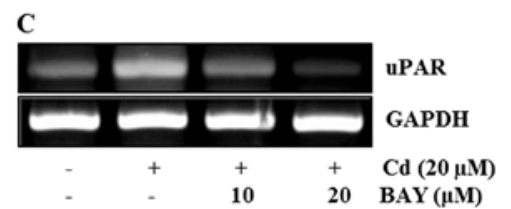

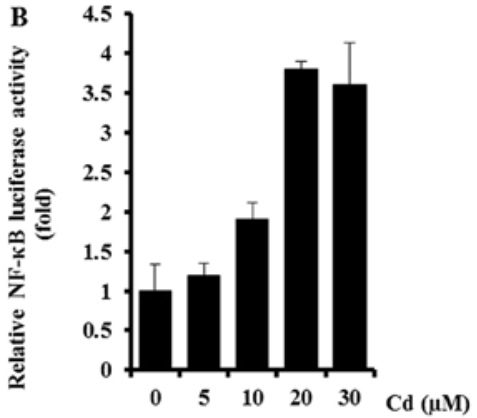

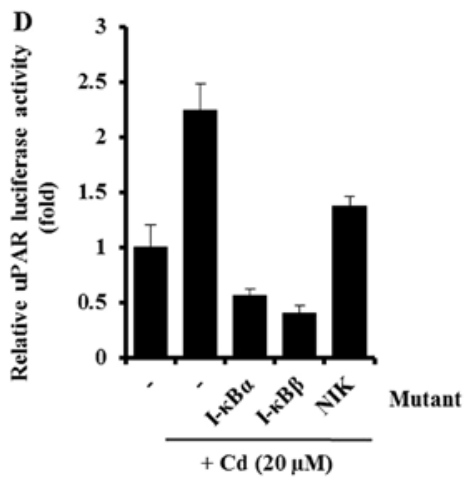

Figure 4. Involvement of transcription factor NF- $\mathrm{BB}$ in cadmium-induced uPAR in gastric AGS cells. The nuclear extracts from AGS cells treated with 0-30 $\mu \mathrm{M}$ cadmium for $4 \mathrm{~h}$ were analyzed EMSA for activated NF- $\mathrm{kB}$ using radiolabeled oligonucleotide probes (A). AGS cells transiently transfected with pNF-KB-Luc-reporter construct were incubated with 0-30 $\mu \mathrm{M}$ cadmium for $4 \mathrm{~h}$. After incubation, the cells were lysed and the luciferase activity was measured using a luminometer (B). AGS cells pretreated with 0-20 $\mu \mathrm{M}$ Bay11-7082 (BAY, NF- $\kappa \mathrm{B}$ inhibitor) for $1 \mathrm{~h}$ were incubated with $20 \mu \mathrm{M}$ cadmium for $4 \mathrm{~h}$. After incubation, uPAR mRNA in the cell lysates were determined by RT-PCR (C). Expression after dominant-negative mutant forms of NIK, I- $\mathrm{kB} \alpha$, or I- $\mathrm{kB} \beta$ were cotransfected with pGL3-uPAR into AGS cells. After incubation with $20 \mu \mathrm{M}$ cadmium for $4 \mathrm{~h}$, luciferase activities were determined using a luminometer (D). The data represent the means \pm standard deviations from triplicate measurements.

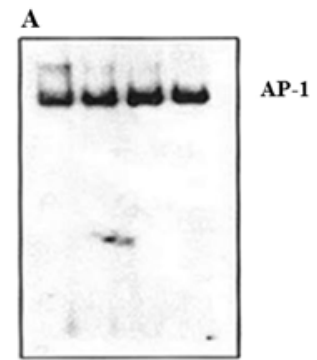

$\begin{array}{lllll}0 & 10 & 20 & 30 & \mathrm{Cd}(\mu \mathrm{M})\end{array}$

C

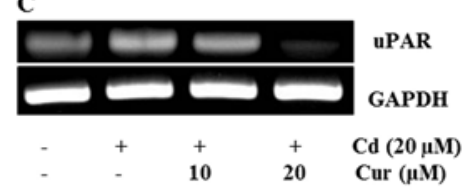

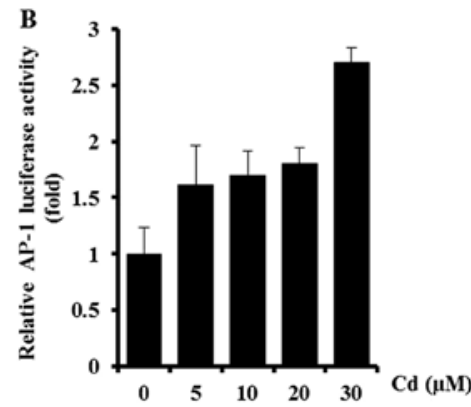

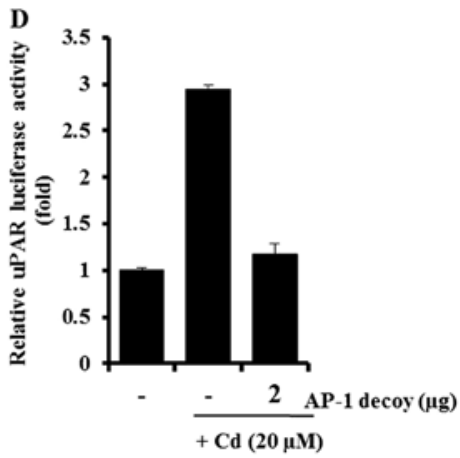

Figure 5. Involvement of transcription factor AP-1 in cadmium-induced uPAR in gastric AGS cells. Nuclear extracts from the AGS cells treated with 0-30 $\mu \mathrm{M}$ cadmium for $4 \mathrm{~h}$ were analyzed using EMSA for activated AP-1 using radiolabeled oligonucleotide probes (A). AGS cells transiently transfected with the pAP-1-Luc-reporter construct were incubated with 0-30 $\mu \mathrm{M}$ cadmium for $4 \mathrm{~h}$. After incubation, the cells were lysed and the luciferase activity was measured using a luminometer (B). AGS cells pretreated with 0-20 $\mu \mathrm{M}$ curcumin (Cur, AP-1 inhibitor) for $1 \mathrm{~h}$ were incubated with $20 \mu \mathrm{M}$ cadmium for $4 \mathrm{~h}$. After incubation, uPAR mRNA in the cell lysates were determined by RT-PCR (C). The AP-1 decoy was cotransfected with pGL3-uPAR into AGS cells. After incubation with $20 \mu \mathrm{M}$ cadmium for $4 \mathrm{~h}$, luciferase activities were determined using a luminometer (D). The data represent means \pm standard deviations from triplicate measurements. 


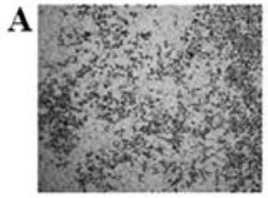

Control

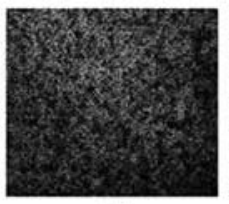

Cd

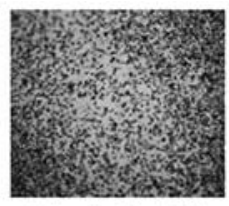

Cd + Anti-uPAR

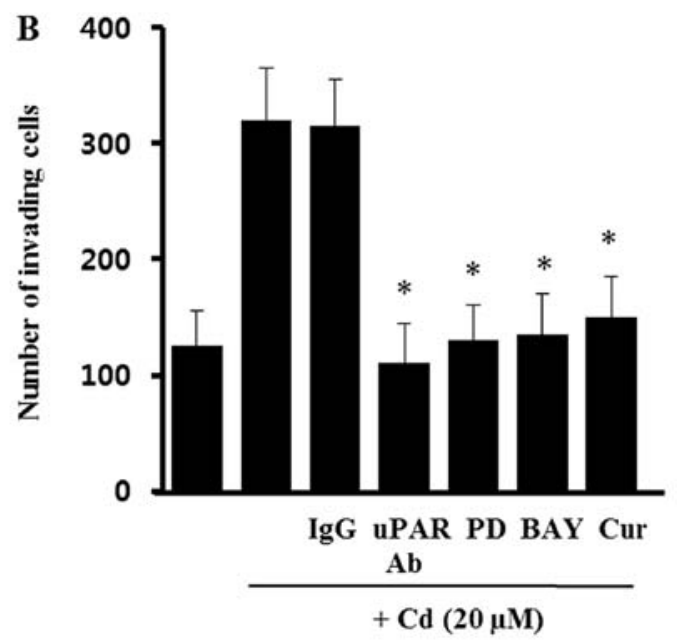

Figure 6. Effects of cadmium on the invasion of AGS cells. AGS cells $\left(10^{5}\right)$ were incubated with $20 \mu \mathrm{M}$ cadmium in the presence or absence of antiuPAR antibody $(50 \mu \mathrm{g} / \mathrm{ml})$ in BioCoat Matrigel apparatus for $24 \mathrm{~h}$. After incubation, the cells that invaded the undersurface of the chambers were counted using a phase-contrast light microscope after staining with the Diff-Quick kit (A). AGS cells $\left(10^{5}\right)$ were incubated with $20 \mu \mathrm{M}$ cadmium for $24 \mathrm{~h}$ in the presence or absence of anti-uPAR antibody $(50 \mu \mathrm{g} / \mathrm{ml})$, non-specific IgG (50 $\mu \mathrm{g} / \mathrm{ml}), 25 \mu \mathrm{M}$ PD98059 (PD), $10 \mu \mathrm{M}$ SP600125 (SP) $5 \mu \mathrm{M}$ SB203580 (SB), $20 \mu \mathrm{M}$ Bay11-7082 (BAY), or $20 \mu \mathrm{M}$ curcumin (Cur). After incubation, the cells that invaded the undersurface of the chambers were counted (B). The data represent means \pm standard deviations from triplicate measurements. ${ }^{*} \mathrm{P}<0.05$, vs. with cadmium alone.

invasiveness after incubation with uPAR-neutralizing antibodies, whereas no such effect was seen after incubation with non-specific IgG. These results suggest that uPAR induced by cadmium has an import role in gastric cancer cell invasiveness. To confirm that ERK-1/2, NF- $\mathrm{BB}$, and AP-1 are involved in the cadmium-induced invasiveness, the AGS cells were treated with PD98059 (MEK inhibitor), BAY11-7082 (NF-кB inhibitor) and curcumin (AP-1 inhibitor) before cadmium treatment. As shown in Fig. 6B, all of the inhibitors (PD98059, BAY11-7082, curcumin) blocked the Matrigel invasiveness induced by cadmium. However, the inhibitors alone did not significantly change the level of cell invasiveness (data not shown). This suggests that the ERK-1/2, NF- $\mathrm{BB}$, and AP-1 signals activated by cadmium upregulate UPAR, leading to an increase in gastric cancer cell invasiveness.

\section{Discussion}

A recent study reported that long-term exposure to cadmium increased the risk of mortality from stomach cancer (2). Because of the widespread use of cadmium, gastrointestinal absorption of cadmium without being aware is unavoidable. Several studies about carcinogenic effects of cadmium have been published and the cytotoxic action and carcinogenesis of cadmium in many organs, especially the lung, liver, breast, and kidney, are well known (16-18). However, the mechanisms underlying cadmium-induced carcinogenesis have remained largely unknown. Much effort has been directed at defining the role of cadmium in cancer development and progression, stimulated by the following observations: i) cadmium emissions have increased dramatically during the 20th century, one reason being that cadmium-containing products are rarely recycled, but are often dumped together with household waste, ii) long-term studies suggest an association between cadmium and cancer development [the biological half-life of cadmium in the human body is $\sim 25-30$ years, so overexposure to cadmium can lead to its accumulation in the human body (19)], iii) the adverse health effects of cadmium exposure may occur at lower exposure levels than previously anticipated, primarily in the form of kidney damage and bone fracture (20), and iv) cadmium induces various genes related to carcinogenesis, including IL-8 and COX-2, which are important for cancer development and angiogenesis $(21,22)$.

In this study, we found that cadmium could induce UPAR expression and stimulate cell invasiveness in human gastric cancer AGS cells, suggesting that the overexpression of UPAR by cadmium may be involved in the increased cell invasiveness. Choi et al (23) demonstrated that overexpression of UPAR in human gastric carcinomas correlated with their invasiveness and tumorigenicity. Previously, we reported that UPAR is upregulated by various stimuli such as $H$. pylori, ROS, and EGF (12) in gastric cancer cells. The serine protease uPA and its receptor UPAR system have the ability to convert inactive plasminogen to active plasmin, which, in turn, activate certain matrix metalloproteinases (MMPs), which break down the collagen components of the extracellular matrix and accelerate tumor invasion and metastasis (24). Cellular responses to cadmium stimulation trigger a cascade of protein kinases that transmit signals from the cell surface to the nucleus and these signals ultimately regulate gene expression. These signaling molecules including epidermal growth factor receptor (EGFR), phosphatidyl inositol 3-kinase (PI3K), AKT, and mammalian target of rapamycin (mTOR) have been reported to be involved in carcinogenesis and cancer progression (25).

Several studies have documented that the MAPKs have roles in cadmium-induced signal transduction, but the profiles of cadmium-induced kinase activation appear to vary in a cell type-dependent manner. Three major MAPKs have been identified in mammalian cells: ERK-1/2, JNK, and P38 MAPK. Our results show that cadmium promoted the activation of ERK-1/2 and induced uPAR expression in human gastric AGS cells. Activation of ERK-1/2, JNK, and p38 MAPK preceded the induction of uPAR mRNA expression, and this upregulation was attenuated by a selective inhibitor of ERK-1/2, suggesting that the ERK-1/2 signaling pathway is implicated in the activation of the UPAR gene by cadmium. This suggestion was further supported by observations that expression of a vector encoding a mutated-type MEK-1 (K97M) resulted in a marked reduction in UPAR promoter activity. It remains to be determined how cadmium mediates ERK-1/2 activation in human gastric AGS cells. Park et al (22) reported that crosstalk between oxidative stress and activation of the family of MAPK in cadmium-treated C6 cells, in which cadmium treatment primarily lowered cellular GSH, subsequently 
leading to activation of ERK-1/2. Multiple pathways have been proposed in different cell types leading to ERK-1/2 activation by ROS. Mukhin et al (26) suggested a simple model for ERK-1/2 activation by ROS (NAD(P)H oxidase $\rightarrow$ Gi $\beta \gamma \rightarrow$ Src $\rightarrow$ ERK-1/2 pathway) using $\mathrm{CHO}$ cells. Concurrent inhibition of tyrosine phosphatase (PTPase) by ROS has been suggested to be another mechanism of ERK-1/2 activation (18). Because all PTPases have a conserved cysteine residue in their catalytic domain, the inhibition of PTPase activity by ROS may account for activation of ERK-1/2 by ROS.

Our results are consistent with those of earlier studies implicating the involvement of transcription factors such as $\mathrm{NF}-\kappa \mathrm{B}$ and AP-1 in uPAR expression in gastric cancer cells (27). Related to this, Valko et al (28) confirmed that metals activate signaling pathways and the carcinogenic effect of metals has been related to activation of mainly redox-sensitive transcription factors, including $\mathrm{NF}-\kappa \mathrm{B}, \mathrm{AP}-1$, and $\mathrm{p} 53$. The roles of NF- $\kappa \mathrm{B}$ with cadmium in cells vary depending on the cell type. NF- $\kappa \mathrm{B}$ is important in cadmium-induced TNF- $\alpha$, IL- $1 \beta$, IL-6, and IL-8 in THP-1 monocytic cells. (29). Furthermore, $\mathrm{NF}-\kappa \mathrm{B}$ activation is apparently involved in cadmium-induced apoptosis in lung epithelia and kidney proximal tubule cells $(30,31)$. However, cadmium induced the proinflammatory cytokine IL-8 in lung epithelial cells in a NF- $\kappa \mathrm{B}$-independent manner. ROS production by cadmium has been suggested to activate NF- $\kappa \mathrm{B}$ in cells. Li and Engelhardt (32) reported that the recruitment of NIK to TRAF6 is mechanistically important for the ROS induction of NF- $\kappa \mathrm{B}$ activation. Storz and Toker (33) showed that protein kinase D (PKD) is essential for ROS-induced NF- $\kappa \mathrm{B}$ activation by inducing tyrosine phosphorylation of IKK. Src and Abl mediate PKD activation in response to $\mathrm{H}_{2} \mathrm{O}_{2}$ stimulation, via the phosphorylation of Tyr463 in the PKD pleckstrin homology domain. Similarly, Fan et al (34) reported that ROS controlled NF- $\kappa \mathrm{B}$ activation through c-Src-dependent tyrosine phosphorylation of $\mathrm{I}-\kappa \mathrm{B}$.

In subsequent experiments, the role of AP-1 in cadmiuminduced UPAR expression was also investigated. The transcription factor AP-1 is composed of Fos and Jun homodimers and heterodimers. Cascades of MAPKs are involved in the activation of AP-1. In our system ERK-1/2 may be supposed to induce c-Fos and AP-1 activity. Escobar Mdel et al (35) reported the role of MAPK induced by cadmium in AP-1 activation in HepG2 cells. AP-1 activation decreased by $74 \%$ with ERK inhibition, by $83 \%$ with p38 inhibition, and by $70 \%$ with JNK inhibition. In mouse epidermal JB6 cells, the induction of AP-1 activity by cadmium appeared to involve activation of ERK-1/2, because the induction of AP-1 activity by cadmium was blocked by pretreatment of the cells with PD98058 (36).

We also found in this study that cadmium can stimulate the cell invasion in AGS cells via overexpression of UPAR. Several laboratories have provided convincing evidence that cadmium enhances cell invasion and tumorigenesis. Juang et al (37) reported that cadmium upregulated metallothionein 3 , an androgen-upregulated gene, and enhanced cell invasion in prostate carcinoma cells. Cadmium also induced cell invasion via $\mathrm{AKT} / \mathrm{GSK}-3 \beta / \beta$-catenin signaling in mouse BEAS-2B cells (10). In conclusion, the present report describes for the first time the role of cadmium in the regulation of UPAR in gastric cancer cells. Further studies are needed to determine the remaining details of the regulatory mechanism.

\section{Acknowledgements}

This study was supported by a research grant (0720570) from the National Cancer Center, by a Basic Science Research Program through the National Research Foundation of Korea (NRF) funded by the Ministry of Education, Science, and Technology (2010-0009910), and by a Medical Research Center (2012-000-9442) grant from the Korean Science and Engineering Foundation.

\section{References}

1. García-Esquinas E, Pollan M, Tellez-Plaza M, Francesconi KA, Goessler W, Guallar E, Umans JG, Yeh J, Best LG and Navas-Acien A: Cadmium exposure and cancer mortality in a prospective cohort: the strong heart study. Environ Health Perspect 122: 363-370, 2014.

2. Wang M, Song H, Chen WQ, Lu C, Hu Q, Ren Z, Yang Y, Xu Y, Zhong $\mathrm{A}$ and Ling W: Cancer mortality in a Chinese population surrounding a multi-metal sulphide mine in Guangdong province: an ecologic study. BMC Public Health 11: 319, 2011.

3. Engström KS, Vahter M, Johansson G, Lindh CH, Teichert F, Singh R, Kippler M, Nermell B, Raqib R, Strömberg U and Broberg K: Chronic exposure to cadmium and arsenic strongly influences concentrations of 8-oxo-7,8-dihydro-2'-deoxyguanosine in urine. Free Radic Biol Med 48: 1211-1217, 2010.

4. Ochi T and Ohsawa M: Participation of active oxygen species in the induction of chromosomal aberrations by cadmium chloride in cultured Chinese hamster cells. Mutat Res 143: 137-142, 1985.

5. Fang MZ, Mar W and Cho MH: Cadmium affects genes involved in growth regulation during two-stage transformation of Balb/3T3 cells. Toxicology 177: 253-265, 2002.

6. Jin P and Ringertz NR: Cadmium induces transcription of protooncogenes c-jun and c-myc in rat L6 myoblasts. J Biol Chem 265: 14061-14064, 1990.

7. Jing Y, Liu LZ, Jiang Y,Zhu Y, Guo NL, Barnett J, Rojanasakul Y, Agani $\mathrm{F}$ and Jiang BH: Cadmium increases HIF-1 and VEGF expression through ROS, ERK, and AKT signaling pathways and induces malignant transformation of human bronchial epithelial cells. Toxicol Sci 125: 10-19, 2012.

8. Qu W, Fuquay R, Sakurai T and Waalkes MP: Acquisition of apoptotic resistance in cadmium-induced malignant transformation: specific perturbation of JNK signal transduction pathway and associated metallothionein overexpression. Mol Carcinog 45: 561-571, 2006.

9. Goldfarb RH and Liotta LA: Proteolytic enzymes in cancer invasion and metastasis. Semin Thromb Hemost 12: 294-307, 1986.

10. Son YO, Wang L, Poyil P, Budhraja A, Hitron JA, Zhang Z, Lee JC and Shi X: Cadmium induces carcinogenesis in BEAS-2B cells through ROS-dependent activation of PI3K/AKT/GSK-3 $3 /$ $\beta$-catenin signaling. Toxicol Appl Pharmacol 264: 153-160, 2012.

11. Waltz DA, Fujita RM, Yang X, Natkin L, Zhuo S, Gerard CJ, Rosenberg S and Chapman HA: Nonproteolytic role for the urokinase receptor in cellular migration in vivo. Am J Respir Cell Mol Biol 22: 316-322, 2000.

12. Baek MK, Kim MH, Jang HJ, Park JS, Chung IJ, Shin BA, Ahn BW and Jung YD: EGF stimulates uPAR expression and cell invasiveness through ERK, AP-1, and NF-kappaB signaling in human gastric carcinoma cells. Oncol Rep 20: 1569-1575, 2008.

13. Shariat SF, Semjonow A, Lilja H, Savage C, Vickers AJ and Bjartell A: Tumor markers in prostate cancer I: blood-based markers. Acta Oncol 50 (Suppl 1): 61-75, 2011.

14. Raghu H, Sodadasu PK, Malla RR, Gondi CS, Estes N and Rao JS: Localization of UPAR and MMP-9 in lipid rafts is critical for migration, invasion and angiogenesis in human breast cancer cells. BMC Cancer 10: 647, 2010.

15. Wang Y1, Dang J, Johnson LK, Selhamer JJ and Doe WF: Structure of the human urokinase receptor gene and its similarity to CD59 and the Ly-6 family. Eur J Biochem 227: 116-122, 1995. 
16. Person RJ, Tokar EJ, Xu Y, Orihuela R, Ngalame NN and Waalkes MP: Chronic cadmium exposure in vitro induces cancer cell characteristics in human lung cells. Toxicol Appl Pharmacol 273: 281-288, 2013.

17. Hyder O, Chung M, Cosgrove D, Herman JM,Li Z, Firoozmand A Gurakar A, Koteish A and Pawlik TM: Cadmium exposure and liver disease among US adults. J Gastrointest Surg 17: 1265-1273, 2013.

18. Lubovac-Pilav Z, Borràs DM, Ponce E and Louie MC: Using expression profiling to understand the effects of chronic cadmium exposure on MCF-7 breast cancer cells. PLoS One 8: e84646, 2013.

19. Hartwig, A: Mechanisms in cadmium-induced carcinogenicity: recent insights. Biometals 23: 951-960, 2010.

20. Järup L: Hazards of heavy metal contamination. Br Med Bull 68 $167-182,2003$

21. Cormet-Boyaka E, Jolivette K, Bonnegarde-Bernard A, RennoldsJ, Hassan F, Mehta P, Tridandapani S, WebsterMarketon $\mathbf{J}$ and Boyaka PN: An NF- $\kappa \mathrm{B}$-independent and Erk1/2-dependent mechanism controls CXCL8/IL-8 responses of airway epithelial cells tocadmium. Toxicol Sci 125: 418-429, 2012.

22. Park YK, Hong $\mathrm{H}$ and Jang BC: Transcriptional and translational regulation of COX-2 expression by cadmium in C6 glioma cells. Int J Mol Med 30: 960-966, 2012.

23. Choi YK, Yoon BI, Kook YH, Won YS, Kim JH, Lee $\mathrm{CH}$, Hyun BH, Oh GT, Sipley J and Kim DY: Overexpression of urokinase-type plasminogen activator in human gastric cancer cell line (AGS) induces tumorigenicity in severe combined immunodeficient mice. Jpn J Cancer Res 93: 151-156, 2002.

24. Festuccia C, Dolo V, Guerra F, Violini S, Muzi P, Pavan A and Bologna M: Plasminogen activator system modulates invasive capacity and proliferation in prostatic tumor cells. Clin Exp Metastasis 16: 513-528, 1998.

25. Carpenter RL and Jiang BH: Roles of EGFR, PI3K, AKT, and mTOR in heavy metal-induced cancer (Review). Curr Cancer Drug Targets 13: 252-266, 2013.

26. Mukhin YV, Garnovskaya MN, Collinsworth G, Grewal JS Pendergrass D, Nagai T, Pinckney S, Greene EL and Raymond JR: 5-Hydroxytryptamine 1A receptor/Gibetagamma stimulates mitogen-activated protein kinase via $\mathrm{NAD}(\mathrm{P}) \mathrm{H}$ oxidase and reactive oxygen species upstream of src in chinese hamster ovary fibroblasts. Biochem J 347: 61-67, 2000.
27. Lee K and Esselman WJ: Inhibition of PTPs by $\mathrm{H}(2) \mathrm{O}(2)$ regulates the activation of distinct MAPK pathways. Free Radic Biol Med 33: 1121-1132, 2002.

28. Valko M, Morris H and Cronin MT: Metals, toxicity and oxidative stress (Review). Curr Med Chem 12: 1161-208, 2005.

29. Freitas M and Fernandes E: Zinc, cadmium and nickel increase the activation of NF- $\kappa \mathrm{B}$ and the release of cytokines from THP-1 monocytic cells. Metallomics 3: 1238-1243, 2011.

30. Napolitano JR, Liu MJ, Bao S, Crawford M, Nana-Sinkam P, Cormet-Boyaka E and Knoell DL: Cadmium-mediated toxicity of lung epithelia is enhanced through NF- $\kappa \mathrm{B}$-mediated transcriptional activation of the human zinc transporter ZIP8. Am J Physiol Lung Cell Mol Physiol 302: L909-L918, 2012.

31. Thévenod F, Friedmann JM, Katsen AD and Hauser IA: Up-regulation of multidrug resistance P-glycoprotein via nuclear factor-kappaB activation protects kidney proximal tubule cells from cadmium- and reactive oxygen species-induced apoptosis. J Biol Chem 275: 1887-1896, 2000

32. Li Q and Engelhardt JF: Interleukin-1beta induction of NFkappaB is partially regulated by $\mathrm{H}_{2} \mathrm{O}_{2}$-mediated activation of NFkappaBinducing kinase. J Biol Chem 281: 1495-1505, 2006.

33. Storz $P$ and Toker A: NF-kappaB signaling - an alternate pathway for oxidative stress responses. Cell Cycle 2: 9-10, 2003.

34. Fan C, Li Q, Ross D and Engelhardt JF: Tyrosine phosphorylation of I kappa B alpha activates NF kappa B through a redoxregulated and c-Src-dependent mechanism following hypoxia/ reoxygenation. J Biol Chem 278: 2072-2080, 2003.

35. Escobar Mdel C, Souza V, Bucio L, Hernández E, Gómez-Quiroz LE and Gutiérrez Ruiz MC: MAPK activation is involved in cadmium-induced Hsp70 expression in HepG2 cells. Toxicol Mech Methods 19: 503-509, 2009.

36. Huang C, Zhang Q, Li J, Shi X, Castranova V, Ju G, Costa M and Dong Z: Involvement of Erks activation in cadmium-induced AP-1 transactivation in vitro and in vivo. Mol Cell Biochem 222: 141-147, 2001.

37. Juang HH, Chung LC, Sung HC, Feng TH, Lee YH, Chang PL and Tsui KH: Metallothionein 3: an androgen-upregulated gene enhances cell invasion and tumorigenesis of prostate carcinoma cells. Prostate 73: 1495-1506, 2013. 